\title{
WHY MEDICINE NEEDS THE CHURCH: REFLECTIONS ON CHRISTIANITY AND MEDICINE IN SOUTH AFRICA
}

\author{
R. Neville Richardson \\ Department of Theological Studies \\ University of Natal \\ PIETERMARITZBURG
}

\begin{abstract}
There is an age-old bond between religion and medicine in which Christianity shanes. While it may seem to many that modem medicine has outgrown that bond, Stephen Toulmin observes that medicine has recently rediscovered its need for ethical neflection and Stanley Hauenwas argues for the central place of medical care in Christian theology and communal life. In South Africa medicine played an important part in the establishment and development of missions, but the place and role of medical mission work has changed. Far from allowing is medical work to fade, the church in South Africa now needs to see that work in a new light, especially in view of the enomous medical needs of the country. A prerequisite to the addressing of those needs is for the church to rediscover itself as a caring community.
\end{abstract}

\section{INTRODUCTORY}

In a world of advanced medical technology, has the Christian church anything to say to the medical fraternity? In South Africa, the land of the first heart transplant, what are some of the moral questions that arise from Christian reflection on medical care? In the process of such reflection, what might the church learn about itself? These are the questions that are to be raised and addressed in this article.

My attention is directed primarily at the underlying purposes and values in terms of which medicine has its meaning and without which it cannot be a coherent practice. While I do not believe that reflection and practice can be separated in a study such as this without violation to both, my main concern in this paper lies with ethical reflection on medicine rather than with the business of doing medicine. My threefold suggestion is that an adequate understanding of the church as Christian community brings to the fore the task of caring for those at hand who are in need, that such an understanding of the church provides a vital key to an adequate ethic for medicine, and that such an ethic is of particular relevance to South Africa. 
Why medicine needs the church: reflections on Christianity and medicine in South Africa

\section{THE RELIGION-MEDICINE RELATIONSHIP}

The close relationship between religion and medicine is older than our historical knowledge of it. Not only do most religions have their healing aspects but, in most primitive religions, healing is an essential element and the various practices of healing are often inextricably bound up with religious rituals. What we understand as 'Western medicine' has its roots in classical Greek and Muslim as well as Judaeo-Christian medical philosophy and practice. The Hippocratic oath which has guided medical practice through many centuries is widely thought to be the late fourth century BCE product of the Pythagoreans who are probably better described as a religious sect than as a philosophical school.

Therefore, historically speaking, a secular setting for the practice of medicine, and especially for critical reflection on that practice, is unusual. For those, however, whose thinking has been formed in a secular setting, it is the religious perspective that is often thought to be unusual. What needs to be recognized is the extent to which religious influences from time immemorial have shaped what we recognize today as medicine. It is the product of a long multifaceted religious tradition and is not merely the product of our modern secular, scientific age - although our age has seen technological advances in medicine which previous ages surely could not even have envisaged.

The post-enlightenment era has also seen the fragmentation of disciplines which once belonged together - most notably for our purposes medicine, ethics and religion. In the last two or three decades, however, medicine has proved to be the arena in which these disciplines have begun to rediscover their need of each other. Stephen Toulmin describes this development and shows that, while the benefits have been mutual among the disciplines concerned, ethics has probably benefited most. The article in which he makes this point has the fascinating title: "How medicine saved the life of ethics" (Toulmin, 1982).

\subsection{Medicine and ethics in a new relationship}

According to Toulmin, medicine has led ethics from the arid wastelands of abstract metaethical theories, subjectivism, relativism and radical individualism, into the fertile crescent of applied ethics. Here ethicists must give their attention to objective and universal conditions shared by all humans, such as sickness, reproduction and death. Secondly they must engage once more in the business of casuistry. By considering particular cases in their uniqueness and detail, analogous to the way in which medicine gos:s about its diagnostic art, something of the art of ethical understanding is redisco. vered. Such a task brings ethics back into its practical role of providing guidance in the 
pursuit of what is good. Thirdly, ethics is once again located primarily in communal rather than in individual considerations, because it must attend to medical practice as a profession and a profession has coherence only with reference to a community with its hopes, expectations, rules and responsibilities. Finally, in the physician-patient relationship we can recover the Aristotelian insight that there is a close connection between relationships and our evaluation of actions. Aristotle pointed out that within different relationships the same words or deeds can represent very different acts. "Words that would be a perfectly proper command from an officer to an enlisted man, or a straightforward order from a master to a servant, might be a humiliation if uttered by a father to a son, or an insult if exchanged between friends." (Toulmin, 1982:747.) Translating this insight into a medical instance, Toulmin says that what might be a perfectly routine deed or utterance by Dr. A towards Mrs. B within the physicianpatient relationship of, say, a gynaecological consultation might be grounds for a claim of assault if performed outside that protected context. Thus we see that situations and relationships do alter cases.

Thinking of the approximate period 1960-1980, Toulmin concludes: "Whatever the future may bring ... these 20 years of interaction with medicine, law, and the other professions have had spectacular and irreversible effects on the methods and content of philosophical ethics" (1982:747).

Toulmin's observations mainly concern philosophical ethics. A similar essay could, however, be written about the resuscitation of Christian ethics. Stanley Hauerwas comments:

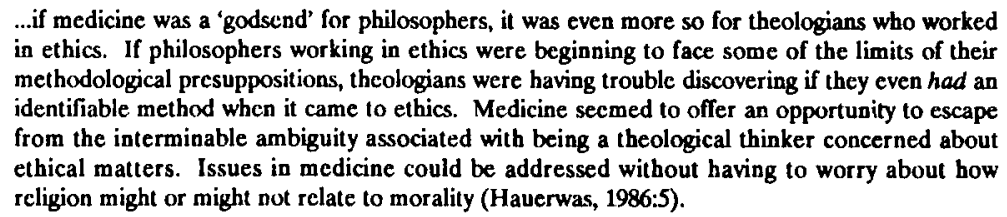

Behind Hauerwas's remark is his view that Toulmin has accurately described a recent development which has indeed placed medicine and ethics in a new relationship, but that ethics has been the main beneficiary and has not as a result changed in its basic methods. 


\subsection{Physician-patient relationship}

Because medical science was so enamoured of the experts in its own ranks, it looked for the 'experts' in ethics to help it solve its new problems. But the ethical experts could do no more than merely impose their own categories and methods on this new rich field of influence. What emerged, for instance, was the debate about patients' rights. While not denying the importance of this issue, Hauerwas contends that it is precisely the kind of thing one would expect to come to the fore among those who operate within the confines of the autonomy-heteronomy debate. Likewise, physicians have been urged by ethicists to understand their duties to patients as mere instances of more general and universal obligations that pertain between any persons. The physician-patient relationship is understood in terms of a legal contract between autonomous individuals, hence "... the temptation to construe medical care in terms of capitalist notions of property becomes almost irresistible, corrupting physician and patient alike" (Hauerwas, 1986:5).

What both medicine and ethics in their new relationship overlook, perhaps even distort, are "the already substantive moral commitments that are constitutive of and embodied in their daily care of patients" (Hauerwas, 1986:4). What Hauerwas sets out to do is to focus on the care which he sees to be at the heart of medicine, and to spell out what it is that we are doing when we engage in the practice called 'medicine'. What we are doing, he suggests, is something at the same time both unavoidably communal and inherently moral.

\subsection{Nature and function of medical ethics}

When theologians are confronted by medical issues they should do far more than merely add 'a Christian perspective' to the moral reasoning that others are doing. Such an icing of the cake is the opportunistic response of theological ethicists for whom medical concerns came as a 'godsend' and of whom Hauerwas is so critical. How then, according to Hauerwas, should theologians respond? The first effect of medical ethics on theologians should be a 'despiritualizing' of their thinking - they should be reminded by medical issues of our bodily and communal nature. Most importantly, he believes that theologians, whether they realize it or not, are specially equipped to help medicine understand itself and its task. Like the original framers of the Hippocratic Oath, theologians should not see themselves as representing a broad consensus of views, but rather the convictions of a small group. ${ }^{1}$

${ }^{1}$ It is true that entire societies and even nations may be caring to a degree. It is on this basis that Sydney Brandon levels a challenge at Britain and its National Health system (Rrandon, 1973: 
Does this imply that Hauerwas, as a Christian theologian, regards the Christian point of view, or perhaps even that of some small group of Christians, as the only one? Is he propounding a form of religious exclusivism? From the above analogy of the Hippocratic Oath alone, it is clear that Hauerwas is not arguing for Christian exclusivity in medical ethics. The very fact that the Hippocratic Oath has nonChristian origins and that he sees Christians sharing with secuiarists and those of other religious traditions a reverence for its vision and values, is cvidence of the nonexclusivity of his position. While being non-exclusivist, however, Hauerwas is community-specific, and the community which is his primary social reference is the Christian church. Furthermore, Hauerwas's compelling view of the church requires that it be a distinctive community within the wider society. As a conscious social minority, its very cultural counterstance is the basis for its social-ethical witness. ${ }^{2}$

\section{THE POSITION OF THE CHURCH IN THE RELIGION-MEDICINE RELATIONSHIP}

The previous point began by noting the age-old relationship between religion and medicine. Christianity's medical concern has its tap root in the synoptic gospel accounts of the healing miracles of Jesus himself. While medical work has often played an important part in the life and witness of the church, not least in South Africa as will be noted in the next section, it seems that it is now widely viewed as an optional addendum to the church and its theology. The point must now be made that care of the sick should be an integral part of the church's embodiment of the gospel and that medical ethics should be regarded as central rather than peripheral to theology. This vital interconnection between the church and medicine has been propounded recently by Stanley Hauerwas.

Following Alasdair MacIntyre (1981), Hauerwas believes that moral understanding is possible in terms of particular languages and traditions, which in turn are possible only within specific communities. He regards the care of the sick as a remarkable enterprise in any community, and the way in which a particular community provides for

135-145). What Brandon means by 'community', however, in bis central question: 'Can the community care?', is not the same as what Hauerwas means by the term. The primary social reference point for Hauerwas is an emphatically Christian community which stands distinct from, and in certain fundamental respects even counter to, the wider society.

2 For a full treatment of Hauerwas's understanding of the church and its moral role see Richardson (1986). 
Why medicine needs the church: reflections on Christianity and medicine in South Africa

the care of the sick in its midst is perhaps the key indicator of the moral character of that community. The setting aside of resources and medical personnel (which, for Hauerwas, is a wide category of all those who are called to be with and to aid the sick) is highly significant in this regard. He wants to see it as striking, even odd, rather than 'natural' or 'normal'.

If any one intuition underlies [my general thinking on medical ethics] it is the recognition of what an extraordinary gesture it is for a society to set aside some to dedicate their lives to the care of the ill. (Hauerwas, 1986:13.)

Such 'an extraordinary gesture' is for Hauerwas only possible to the extent that a community is 'peaceable' and a peaceable community is 'finally possible'

... not when there is merely a willingness to live and let live, but only when freedom is supported by a profound commitment to the protection and care of each person's life (1986:14).

The final test case for Hauerwas is the ability of any given society to care for the mentally handicapped in its midst - for they are the ones most different from ourselves and their difference is most threatening to our sense of normality. His primary argument in medical ethics is "that a humane medicine is impossible to sustain in a society which lacks the moral capacity to care for the mentally handicapped" (1986:18).

The way in which 'good' physicians in Germany were unable to find moral resources wherewith to stand against the medical practices of the Third Reich raises for both Hauerwas and Maclntyre (1977: 25-29) the question of where medical ethics are to be grounded. ${ }^{3}$ For both, that grounding can only be in a distinctive community which, for MacIntyre, seems to be something like the church once used to be but can no longer be, and for Hauerwas it is the Christian community which he sees existing concretely, or at least potentially so, in every gathering of Christians. The well-known opposing attempts to ground medical ethics in consequences (Fletcher, 1979) ${ }^{4}$ and in the biblical covenant principle (Ramsey, 1970) both fail to ground medical ethics in something distinctly Christian. To Hauerwas, Fletcher's agape sounds as biblical as Ramsey's

\footnotetext{
${ }^{3}$ Hauerwas reflects on this general moral point in the case of the career of Albert Speer. He suggests that Speer lacked an alternative source of moral vision, and therefore lacked the means of evaluating truthfully the invitation to become the 'greal' architect and planner of the Third Reich. Sec Stanley Hauerwas (with David B. Burrell, 1977).

4 Joseph Fletcher's situational approach to ethics in general is well known, but a clear explanation of the way in which it applies in particular to medical ethics is to be found in his Humanhood (1979: 5).
} 
covenant fidelity, but as an ethical touchstone it turns out to be theologically uncontrolled and Ramsey's covenant principle turns out to underwrite a natural law ethic whose theological status is unclear. ${ }^{5}$

Hauerwas points in a different direction for the grounding of medical ethics. He points to the kind of community necessary to sustain the care of the ill, especially the longterm ill and the mentally handicapped. Hauerwas points to his primary concern thus:

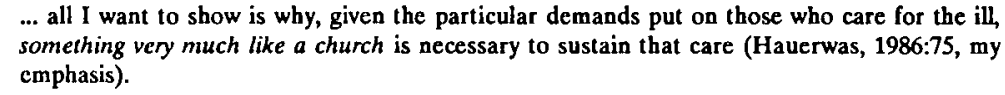

What this amounts to is a view of the church as a role model for the wider medical fraternity. But if the intention is to provide coherent moral guidance for the practice of medicine, then this role model would generate a double-edged normativity. For if the medical fraternity is to look for an empirical instance of such an ecclesial role model, where is such a church to be found? Unless there is at least one concrete instance of a caring, responsive community of Christian people, then the guidance being offered is vacuous. What is the use of suggesting a role model for medical ethics when no concrete example of the role model is to be found? In trying to suggest a coherent morality for the medical community, Christian ethicists like Hauerwas find themselves and their own primary community of reference, the church, severely tested! Clearly Christian communities and the theologians who interpret their own life and articulate their tasks for them are faced here with a profound and searching challenge. To the extent that they consider the church to be such a role model, they are obliged to work to develop the kind of church that is capable of being a role model for the practice of medicine.

Should there be such a church, however, and an accompanying ethic which is not only coherent, but substantively Christian, then the implications for medical ethics and indeed for a fundamental understanding of the nature and purpose of the practice of medicine would be far reaching. I want to make the theologically normative point that there ought to be such a church and that such a church is in fact a sine qua non of Christian ethics. If there is no such church and no such embodiment of Christian guidance for medical ethics, then that is a terrible indictment on all who claim to be Christian - and in South Africa at present that is three quarters of the population. 6

\footnotetext{
5 Hauerwas's criticism of Ramsey would also apply, of course, to much of the thinking on medical ethics by Roman Catholic moral theologians - a recent example of which is to be found in John Mahoney (1984). See especially his notion of the perfecting of humanism, p.110.

${ }^{6}$ In the 1980 census, $77 \%$ of the cntire population of South Africa claimed to be Christian.
} 


\title{
4. CHURCH AND MEDICINE IN SOUTH AFRICA.
}

In his valuable article on Christian medical missions in South Africa, Clifford Allwood says:

\begin{abstract}
Caring, healing and education have always been at the cutting edge of the church's life. Today pioneering may not be in the bush but in the squatter camps, in forced removal communities or in the concrete jungle - wherever the poor, the captive, the blind, the oppressed and the alienated live (Luke 4:18). Some of the people most captive, poor, blind and stressed are - as was the case with the church at Laodicea (Rev. 3:14 $\mathrm{f}$ ) - to be found among the so-called rich and affluent. In the mission of healing the sick there needs to be innovative thinking by the Body of Christ. This will involve theologians, laity and health care professionals of all kinds: nurses, doctors, social workers and psychologists. There need not be a national policy with a vast bureaucracy, but small dynamic flexible groups of Christians who respond appropriately to the $c y$ of their neighbours. Healing comes through a loving heart, an outstretched hand, and a cup of cold water in the name of Christ. (Allwood, 1989:123-124; my emphasis) ${ }^{7}$
\end{abstract}

It is not the task of this paper to provide historical substantiation for Allwood's comment. Three of his points, however, are of central significance for our purpose. The first is his basic affirmation of the healing ministry of the church. The second is his suggestion that this ministry does not need vast financial and other material resources, say on the level of a national health scheme, in order to function effectively. The third is that the church's medical enterprise does need a wide range of human resources, not all of them trained 'experts', and that the key factor is Christian communal commitment - in Allwood's words: "... small dynamic flexible groups of Christians who respond appropriately to the cry of their neighbours."

It is clear that Allwood sees medical missionary work to have undergone significant changes since the days of the 'mission field' of the nineteenth and early twentieth centuries. He rightly understands mission to be to urban as well as rural areas. But in South Africa even the rural mission hospitals have seen great changes, especially in terms of funding and control. Where once they were the sole property and responsibility of churches and missionary agencies (usually with substantial state aid), they are now largely under state control. One senses that the handover, far from always being reluctant, was often accompanied with a measure of relief, even where churches may have been seriously at odds with the apartheid policies of the government. For instance, in the $1950 \mathrm{~s}$, a commentator on the medical missions of the Methodist Church of Southern Africa said:

\footnotetext{
${ }^{7}$ Dr. Clifford Allwood is an ordained minister of the Methodist Church of Southern Africa. After some years as a medical missionary at the Manguzi Hospital in northern Zululand, he is now Head of Psychiatry at Baragwanath Hospital, Johannesburg.
} 
If the Church is to continue to operate mission hospitals there would appear to be no alternative but to enter into negotiations with the Government for the sale of the sites on which the hospitals stand. In this way the major problem of fmancing, development and maintenance would be solved. (Bennett, s.a.:59-60.)

But was the sense of relief merely a pragmatic response to the burden of sustaining growth and increasing levels of sophistication, or is it an indication of a diminishing enthusiasm for medical mission and even of a shift from the evangelical theology that underpinned it? By the middle of this century, the maintenance of the hospitals was indeed becoming an ever more serious financial burden on churches and missionary societies. The pragmatic line of reasoning is that by then the medical missionaries had fulfilled their role in establishing the hospitals and that a time had been reached when it was appropriate to hand these now technologically sophisticated and financially demanding institutions over to the state with its larger resources. This favourable interpretation would be more convincing if the churches and missionary agencies involved had then launched out once again into this area of enormous need and had established new, less sophisticated medical facilities so that they in turn might develop and be taken over by the secular authorities at some future stage. That this did not happen on any significant scale raises the question as to whether the handover by the churches to the state was not only motivated by expediency, but that the original convictions which gave rise to church-based medical agencies in the first place had changed.

Precisely what those original convictions were is also open to debate. Here Allwood sees a spectrum bounded at one end by "those who provided a service to the poor simply out of compassion for their needs" and, at the other, by "those who believed that salvation of the soul was all-important and that hospitals and schools were a vehicle through which to bring the Gospel to the sick" (Allwood, 1989:116). One suspects that the latter end of the spectrum, the use of medical facilities as a vehicle for evangelization, was where the dominant convictions were originally located and out of which the vision and great energy sprang for the establishment of those facilities.

\subsection{The connection between medicine and the gospel}

More recently the connection between medicine and the Christian gospel has become less clear. Many medical workers who are Christian now operate in a secular framework and, according to at least one missionary doctor, Gerrit Ter Haar, there is a clear advantage in this arrangement. He writes: 


\begin{abstract}
I honestly believe that having no power in a worldly sense is to my advantage as a modern missionary. I have often complained about it, but I have come to the realization that it is to my advantage. When I have no more power to do what I want to do, I am dependent on the working of the Holy Spirit when it comes to convincing people. I cannot force my way. It is a gentle way. I also propose that we drop the term 'missionary' because there are so many bad connotations to it. We should simply be witnessing Christians because in our day all of us share in the privilege and challenge to take part in the ministry of reconciliation. (G. Ter Haar, 1986, quoted in Allwood, 1989: 117-118)
\end{abstract}

Is this way of relating medical practice to Christian convictions so different from that of the early missionaries? I do not think so. Once again we see the practice of medicine being used as a vehicle for the gospel rather than as a service to the poor simply out of compassion for their needs. What has changed is the context. Now the secular society provides the medical infrastructure for such Christian medical work by individual practitioners.

A change can now be detected, however, at another level - that of missionary theology. It seems also that the gospel which fires the mission endeavour has changed with the vehicle. No longer is the gospel understood primarily as salvation from sin and the consequent eternal damnation in the light of which physical suffering pales into insignificance, it is rather 'the ministry of reconciliation' - a very this-worldly concern. Perhaps, in the case of many modern Christian medical workers, the other end of the spectrum of Christian convictions has now come to the fore - that of serving the poor simply out of compassion for their needs. This seems appropriate for, while the traditional picture and location of the 'mission station' and 'mission hospital' may have changed, the call for Christians to 'respond appropriately to the cry of their neighbours' in South Africa is as least as loud as it ever was.

\title{
4.2 Medical resources and socio-economic context
}

A most serious challenge facing the church in its medical role in South Africa springs from the social and economic context. The enormous disparities in wealth distribution in the country are closely bound up with the relative availability and accessibility of medical resources among the various sections of the population. An evaluation of the educational structures of the country says: "South Africa is essentially a Third World

\footnotetext{
${ }^{8}$ Dr. Gerrit Ter Haar came to South Africa from the Netherlands as a missionary doctor in 1956. When mission hospitals in the Transkei were nationalised he decided to stay on and continue his long service at Rietvlei Hospital, Stafford's Post.
} 
country with some complicated pockets of First World privilege" (Moulder, 1988:10). The same observation could validly be made in regard to the medical resources and facilities of the country. For example, while South Africa's overall doctor-population ratio shows up very poorly on a comparative table for industrialised countries, it is the disparity of distribution of doctors that is even more striking. In the early 1980 s the overall South African ratio was 1:1842, but in the most poorly served of the 'homelands', Qwa-Qwa, the doctor-population ratio was a shocking 1:116000 (Pillay, 1984:4-5). The doctor-population ratio is, of course, only one of many interlocking indicators. Similar statistics could be given concerning hospitals, nurses, clinics, pharmacists, as well as of the availability of basic necessities for a healthy life, such as nourishing food and the accessibility of potable water. It is sadly true that: "in the rural areas, especially the homelands, the S.A. government has largely abdicated its responsibility to provide health services to the 'homeland' health departments which accord a low priority to this aspect of development" (Jinabhai, Coovadia, and AbdoolKarim, 1984:11).

The difficulty of maintaining even a semblance of modern medical facilities in a periurban, let alone a rural area, was demonstrated in a front page report in The Natal Witness (1990:1) concerning the obstetrics and gynaecology department of the Edendale hospital. The hospital serves the vast Pietermaritzburg, Natal Midlands and Northern Natal region and the department in question was reported to be in imminent danger of closing down due to the dearth of qualified staff. Ironically, should the unit close, the hospital would lose its status as a training centre for obstetrics and gynaecology, thereby further diminishing the supply of trained personnel and making an already bad situation far worse. One has the strong sense of the jungle closing in on the clearing made by the intrusion of the First World.

\subsection{Distribution of resources - a moral question}

Such a situation, which seems not untypical of present trends throughout the country, may be considered on a pragmatic level and questions may be raised concerning resources and organisation. But the distribution of resources is also a moral question and a particularly pressing moral question where medical matters are at issue. The pressing moral question in the case outlined above would include the reasons for the departure, and in some cases the emigration to lucrative positions in affluent First World countries, of the suitably qualified staff necessary to operate such an important department. A more general moral question applying to the country as a whole is whether it is justifiable for highly sophisticated, expensive medical facilities to be 
Why medicine needs the church: reflections on Christianity and medicine in South Africa

available for a very small section of the population, while the majority of the people have only limited access to even the most rudimentary clinic.

This moral question is faced by Bruno Reichart (1985:8) who asks:

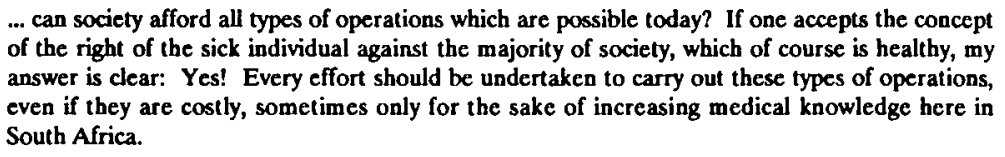
of the right of the sick individual against the majority of society, which of course is healthy, my answer is clear: Yes! Every effort should be undertaken to carry out these types of operations, even if they are costly, sometimes only for the sake of increasing medical knowledge here in South Africa.

This point of view may have some validity in those countries with a reasonably good minimum level of health care available to all. It does not seem to be morally acceptable in Third World countries like South Africa. Reichart's concluding remark indicates a certain level of awareness of South Africa's pressing health care problems. "Even at times when there are great demands on the financial resources available, we must always remember that support of research today will lead to profit for the community in the future." Certainly there are great demands on South Africa's available financial resources, and the principle of sacrificing by the community of today in the interests of the community of the future would be commendable if the circumstances were normal. It must be asked, however, whether Reichart has given adequate consideration, not only to the socio-economic realities of present day South Africa, but also to the moral implications of the medical policy which he is advocating.

At the heart of this paper's concern is the moral nature of communities. Health care, especially for those who need it most, is taken to be a key indicator of that moral nature. What sort of society is it in which costly research is pursued, the benefits of which can only be available to the very few who can afford them, while the majority of the people lack the most basic health care facilities? What kind of 'community of the future' is such policy likely to generate, and precisely who in that future community is likely to 'profit' from such research?

The response called for from the Christian church in South Africa is twofold. First, it should speak with a loud, united voice in favour of the equitable restructuring and redistribution of medical resources. Second, it should demonstrate clearly in its own communal life the kind of costly care, both among its members and by its members towards others, that it would like to see mirrored in the medical policies and practices of the wider society. 


\section{IN CONCLUSION - CHRISTIANITY, MEDICINE AND THE THIRD WORLD.}

How can a largely Third World context sustain a First World medical system? Ought such a context even to try? What alternatives might be considered? I am aware of my audacity in presuming to have something to say to the medical fraternity about questions such as these and about their profession in general. My primary concern, however, is the relation of Christianity to medicine. Whether or not the medical professionals are inclined to listen to such a concern is not my chief worry, for I am focusing more on the church and its theological convictions about medicine than on the details of medical practice itself. I am encouraged, however, by the fact that in recent decades Christian theologians have been among those consulted by medical experts when faced with difficult moral decisions in the medical field.

Also in recent decades, however, the vast majority of works published on medical ethics are concerned with medical practice in the First World. Books on the subject bristle with questions related to sophisticated medical technology. The issues they select and the examples they give are from the context of scientifically advanced, very expensive medical care and experimentation. That is to be expected because that is the context of the medicine which, as Toulmin has reminded us, recalled the services of the ethicists and theologians to help it with its new problems.

The issues of First World medicine, however, strike us only tangentially in South Africa. I am not saying we should ignore them entirely. This is after all, as noted at the outset, the land of the first heart transplant. There may be some validity in Reichart's point that medical research will in the long term future benefit the whole population of the country. Nor is this entirely a hypothetical validity. Even now some of the very poor of the land do benefit from sophisticated techniques and highly expensive facilities. Yet this is also a land disgracefully and disastrously lacking in even the most basic health care for millions of its people. It is the juxtaposition of these considerations that makes the South African case so morally pressing.

\subsection{Care by the Christian community}

Hauerwas addresses the situation in the United States, but his main argument is highly relevant to South Africa's medical situation. His emphasis on care by the community will surely find familiar echoes in much traditional African thinking about medicine. But what is to be said of the Christian community which is so central to his ethical 
reflection? After such a promising start with its medical missions in the nineteenth century and the first half of the twentieth century, what does the South African church now propose to do in the face of such overwhelming needs, and what kind of role model can it be in helping the wider community's ability to care for the ill, especially the long-term ill, and the mentally handicapped?

Allwood, who is clearly a South African ally for Hauerwas, suggests that the church must continue to respond to the need 'on the doorstep', as did the early Christian missionaries in South Africa. He elaborates:

\begin{abstract}
Medical missions specialized in low cost health care, believing that education and prevention were much cheaper than active treatment. Salaries wcre low; simple but effective and inexpensive medicines were used. There are still many ways in which a little expertise from a doctor can be made to go a long way. Village health workers can do a great job with limited training. Ministering to the sick is not the prerogative of doctors only - it is the duty of the whole Christian community. (Allwood, 1989: 123 my emphasis)
\end{abstract}

Underpinning Allwood's thinking, made explicit by Hauerwas, and informing this paper, is an ethic which is emphatically Christian and which has its primary social locis in a community of people which stands out as distinctively Christian in an increasingly secular society. Such a church has something vital to offer the medical fraternity, especially at the level of understanding the fundamental moral significance of medical care. Medical ethics needs such a church - not least in South Africa.

\title{
6. BIBLIOGRAPHY
}

ALLWOOD, C. 1989. Mission as healing the sick: Christian medical missions in South Africa. Missionalia, 17(2):115-125. August.

ANON. 1990. The Natal Witness: 1 . June 19

BENNETT, H.M. s.a. Medical missions. (In Garrett A.E.F., ed. South African Methodism: Her missionary witness. Cape Town : Methodist Publishing Housc. p. 50-61.)

BRANDON, S. 1973. Can the community care? (In Melinsky, M.A.H., ed. Religion and medicine. London : SCM. p. 135-145.)

FLETCHER, J. 1979. Humanhood: Essays in biomedical ethics. Buffalo, New York : Prometheus Books.

HAUERWAS, S. 1977. Truthfulness and tragedy: Further investigations in Christian ethics. Notre Dame : University of Notre Dame Press.

HAUERWAS, S. 1986. Suffering presence: Theological reflections on medicine, the mentally handicapped, and the church. Notre Dame : University of Notre Dame Press.

HAUERWAS, S. \& BURRELL, D.B. 1977. Self-deception and autobiography: Reflections on Speer's "Inside the Third Reich". (In Hauerwas, S. Truthfulness and tragedy: further investigations in Christian ethics. Notre Dame : University of Notre Dame Press. p. 82-98.) 
JINABHAI, C.C., COOVADIA, H.M., \& ABDOOL-KARIM S.S. 1984. Socio-medical indicators for monitoring progress towards health for all in Southern Africa. (In Second Carnegie Inquiry into Poverty and Development in Southern Africa. Volume 10, Health. Cape Town. Separate articles have their own page numbering.)

MACINTYRE, A. 1981. After virtue. London: Duchworth.

MACINTYRE, A. 1977. Can medicine dispense with a theological perspective on human nature? (In Engelhardt, H.T. and Callahan, D. eds., Knowiedge, value and belief, 2. Hastings-on-Hudson, New York : Hastings Center. p. 25-43.)

MAHONEY, J. 1984. Bioethics and bclief: Religion and medicine in dialogue. London : Sheed and Ward.

MOULDER, J. 1988. "Africanising" our universities: Some ideas for a debate. Theoria, 72:1-15. Oct.

PILLAY, P.N. 1984. The distribution of medical manpower and health care facilities in South Africa. (In Second Carnegie Inquiry into Poverty and Development in Southern Africa. Volume 10, Health. Separate articles have their own page numbering.)

RAMSEY, P. 1970. The patient as person: Explorations in medical ethics. New Haven : Yale University Press.

REICHART, B. 1985. Crossing the borders in heart surgery: Simple thoughts. Cape Town : University of Cape Town (Inaugural Lecture Series, 103).

RICHARDSON, R.N. 1986. Christian community and ethics: Critical reflections on the nature and function of the church in the ethics of Stanley Hauerwas. Pietermaritzburg. (Unpublished PhD thesis. University of Natal.)

THE NATAL WITNESS, 1990. June 15.

see

ANON

TOULMIN, S. 1982. How medicine saved the life of ethics. Perspectives in Biology and Medicine, 25(4):736-750. Summer. 
